\title{
Ozone Generation by Applying Electrode Tip with Aluminum Plate
}

\author{
Siseerot Ketkaew* \\ Faculty of Engineering, Thailand \\ *Corresponding author: Siseerot Ketkaew, Faculty of Engineering, Thailand
}

Submission:

\begin{abstract}
This article presents the development of ozone generation by applying corona cell. The high voltage direct current switching power supplies the principle of the fly back converter to use. And control of power MOSFET\#IRFP460 with IC\#TL494 at $15 \mathrm{kHz}$ frequency through the high voltage switching transformer. Inputs of $0.1 \mathrm{amps}, 0.2 \mathrm{amp}$ and $0.3 \mathrm{amps}$ are used to obtain a DC voltage of $2 \mathrm{kV}, 3 \mathrm{kV}$, and $4 \mathrm{kV}$. AC power input at $220 \mathrm{volts}$ to apply to the electrode array located at $1 \mathrm{~cm}$ away from the aluminum plate in the corona cell series. Designed to work 1 hour, the machine can produce ozone gas $1.2 \mathrm{ppm}$ to $3.5 \mathrm{ppm}$.
\end{abstract}

Keywords: Ozone; Converter; Electrode; High voltage; Corona

\section{Introduction}

Past and present, ozone has been used in industrial and everyday life. In practice, it is seen that ozone has both advantages and disadvantages. It depends on how much ozone is used. As a result, the idea is to adjust the amount of ozone to maximize the benefits to the industry and society. Using the method developed ozone gasifier. This is based on adjusting the intensity of the electric field (i.e. adjusting the high voltage direct current) to control the amount of ozone. This gas is formed by the dissociation of oxygen molecules which is the creation of high power switching power supply switching. The TL494 is a pulse modulator and is a control circuit of the power switch MOSFET in the flyback converter. High-frequency transformers are used to induce pulse signals. To build high voltage Apply it to the corona battery pack. By electric power from the corona series it is a factor that directly affects performance. And the type of material used to make corona cells must be conducive to the corona discharge process. To break down the oxygen molecules from the equation:

$$
\mathrm{O}_{2}+\mathrm{O} \rightarrow \mathrm{O}_{3}
$$

Therefore, this research has to experiment with adjusting the input current by observing the high voltage output voltage. To see the amount of ozone produced. And in the future, it will be used to test the reduction of toxic gases such as hydrocarbons. Hydrogen sulfide and deodorize as well as kill germs in the air.

\section{Method to Produce Ozone Gas (O3) in Corona Cell}

Corona cell kits will give air around the electrode tipped is discharged by feeding high voltage direct current to the electrode tipped. This will cause a high intensity electric field on the electrode tipped surface. And when the air enters the air, it breaks down causing ozone. (Ozone gas is the ozone in the 3 atomic states $\mathrm{O}_{3}$ is caused by the use of high voltage. Shake the oxygen molecules by the coronal discharging method in two states $\mathrm{O}_{2}$ atoms break down and combine into oxygen molecules $\left(\mathrm{O}_{3}\right.$ to get ozone $)$.

Ozone gas is produced in the following way.

A. The material or raw materials used to produce ozone are two.

a. Use dry air

b. Use pure oxygen

B. Ozone generator can be separated as follows.

a. We call it Corona Discharge is divided into two types, frequency, low frequency and high frequency for hot weather and high frequency humidity is better. It can produce ozone concentration is higher

b. Use ultraviolet (UV) lamps to produce low concentration ozone. It is used in the air treatment for water treatment is rarely suitable. Because the dissolution is very low, it is not effective.

\section{Design of Corona Cell}

\section{Corona series}

Corona units consist of electrode tipped away from the aluminum plate which is the reverse voltage. Considering the 
electric field stress of a corona series the following equation (1)

$$
E=\frac{V}{d \times \eta^{*}}
$$

E=Electric field intensity

$\mathrm{V}=$ Voltage

$\mathrm{d}=$ Distance between electrode tip and aluminum plate

$\eta^{*}=$ electric field factor

Therefore, the electrode array is selected using electrode tip. The distance from the aluminum plate (d) is $1 \mathrm{~cm}$ (Figure 1).

\section{Calculation of high voltage direct current}

Ozone generator sets. The distance between the electrode array and the aluminum plate (d) is $1 \mathrm{~cm}$ and $\eta^{*}$ equals 0.2 , so the high voltage direct current is equal to

$$
V=E \times d \times \eta^{*}
$$

Table 1: Input current, input voltage, output high voltage and ozone gas quantity. (which adjusts the frequency to $15 \mathrm{kHz}$ to be stable). Ozone Analysis using PHOTOMETRIC O3 ANALYZER-MODEL 400E of ALS LABORATORY GROUP (THAILAND) CO., LTD.

\begin{tabular}{|c|c|c|c|}
\hline Input Current (Ampere) & Input Voltage (Volt) & Output High Voltage (Kilo-Volt) & Ozone Gas Quantity (ppm) \\
\hline 0.1 & 220 & 2 & 1.2 \\
\hline 0.2 & 220 & 3 & 2.7 \\
\hline 0.3 & 220 & 4 & 3.5 \\
\hline
\end{tabular}

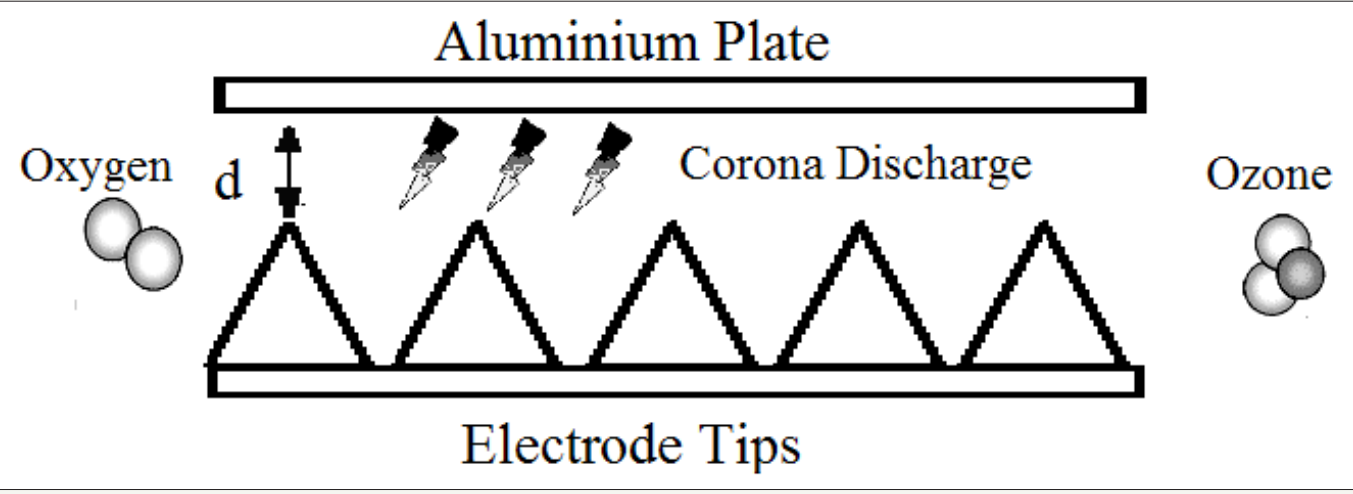

Figure 1: Corona cell.

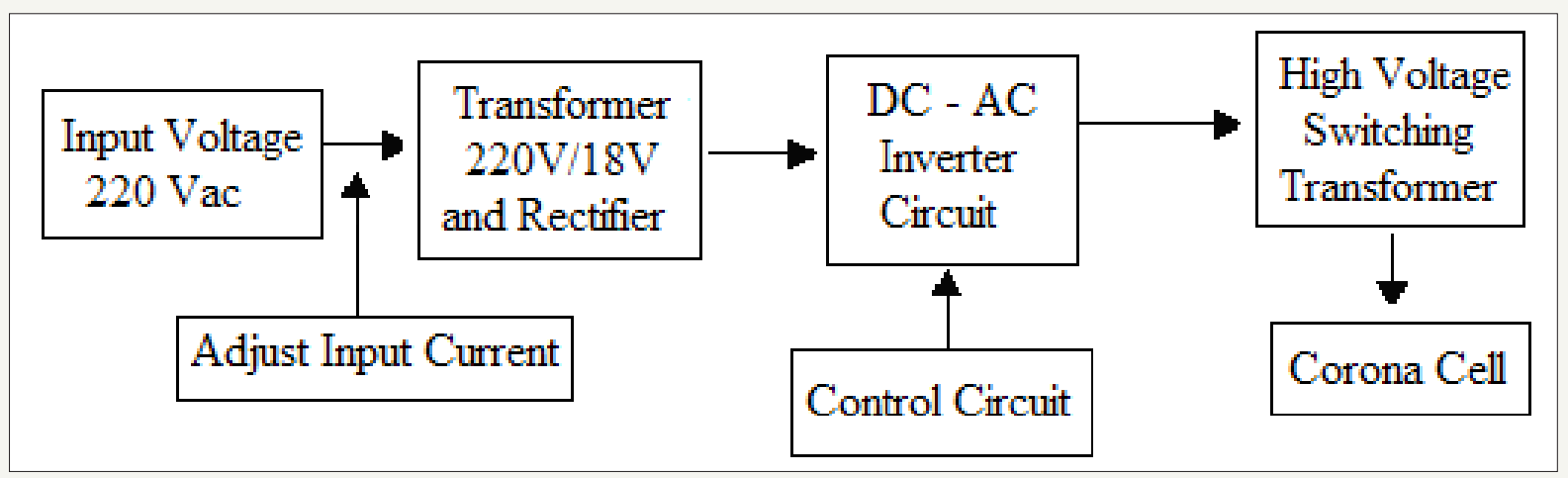

Figure 2: Block diagram of high voltage DC switching power supply structure. 


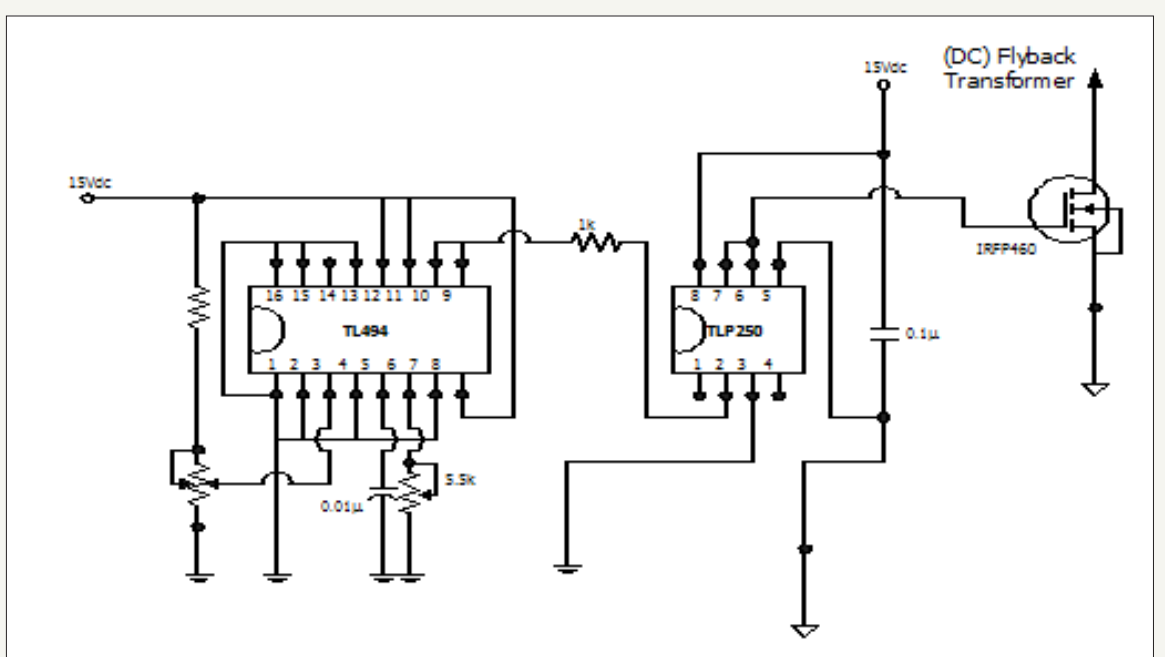

Figure 3: High voltage DC high voltage DC switching power supply.

\section{Conclusion}

In this research, the ozone generator was designed and constructed. In testing, the input voltages were set at 220 volts, with input currents of 0.1 ampere, 0.2 ampere, and 0.3 ampere, resulting in higher DC input voltage values as input currents. It is $2 \mathrm{kV}, 3 \mathrm{kV}$ and $4 \mathrm{kV}$ to supply to corona. In the results of Table 1 , it can be seen that, as the input current increases, the intensity of the electric field increases, increasing the amount of ozone. This is because when the intensity of the electric field increases, the molecules of oxygen increase. As a result, the amount of ozone is increased. So in the future, the researchers will bring the ozone to be used to eliminate other toxic gases. And stink in the food industry. It can be developed into a commercial product.

\section{References}

1. Ketkaew S (2012) Plasma ozonizer using micro-converter for ammonia $\left(\mathrm{NH}_{3}\right)$ decreasing in shrimp food production. Procedia Engineering 32: 148-154.
2. Ketkaew S (2012) Ozone generator using corona for stinky remedies. The electrical engineering network conference. Rajamangala University of Technology Suvarnabhumi, Thailand, pp. 617-620.

3. Ketkaew S (2012) High voltage direct current design small size. Sustainable Rural Development, Local community Foundation for ASEAN Economic Community Development Committee on Higher Education Associated with Khon Kaen University, Thailand.

4. Ketkaew S (2007) The case study of $5 \mathrm{kHz}-25 \mathrm{kHz}$ high frequency adjustment in converter circuit to generate ozone gas. AU JT 11(1): 4247.

5. Ketkaew S (2005) The study of ozone gas generating technique using high frequency, high voltage dc switching power supply of high ripple voltage (in Thai). Journal of King Mongkut's Institute of Technology Ladkrabang 22(2): 1-6.

6. Dun S (2016) Technique \& design of switching power supply. Intelthai, Thailand.

7. TL 494 Data sheet (2002) Pulse-width-modulation control circuits. Texas instruments, USA, pp. 1-10.
Creative Commons Attribution 4.0 International License

For possible submissions Click Here

\section{Submit Article}

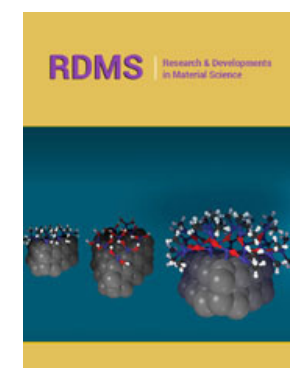

\section{Research \& Development in Material Science}

\section{Benefits of Publishing with us}

- High-level peer review and editorial services

- Freely accessible online immediately upon publication

- Authors retain the copyright to their work

- Licensing it under a Creative Commons license

- Visibility through different online platforms 